Article

\title{
Early Age Carbonation Heat and Products of Tricalcium Silicate Paste Subject to Carbon Dioxide Curing
}

\author{
Zhen $\mathrm{Li}^{1}$, Zhen $\mathrm{He}^{1, *}$ and Yixin Shao ${ }^{2}$ \\ 1 State Key Laboratory of Water Resources and Hydropower Engineering Science, Wuhan University, \\ Wuhan 430072, China; lizhen2012@whu.edu.cn \\ 2 Department of Civil Engineering and Applied Mechanics, McGill University, 817 Sherbrooke Street West, \\ Montreal, QC H3A 2K6, Canada; yixin.shao@mcgill.ca \\ * Correspondence: hezhen_whu@sina.com; Tel.: +86-027-68774396
}

Received: 16 April 2018; Accepted: 3 May 2018; Published: 4 May 2018

\begin{abstract}
This paper presents a study on the carbonation reaction heat and products of tricalcium silicate $\left(\mathrm{C}_{3} \mathrm{~S}\right)$ paste exposed to carbon dioxide $\left(\mathrm{CO}_{2}\right)$ for rapid curing. Reaction heat was measured using a retrofitted micro-calorimeter. The highest heat flow of a $\mathrm{C}_{3} \mathrm{~S}$ paste subject to carbonation curing was 200 times higher than that by hydration, and the cumulative heat released by carbonation was three times higher. The compressive strength of a $\mathrm{C}_{3} \mathrm{~S}$ paste carbonated for $2 \mathrm{~h}$ and $24 \mathrm{~h}$ was 27.5 $\mathrm{MPa}$ and $62.9 \mathrm{MPa}$, respectively. The 24-h carbonation strength had exceeded the hydration strength at 28 days. The $\mathrm{CO}_{2}$ uptake of a $\mathrm{C}_{3} \mathrm{~S}$ paste carbonated for $2 \mathrm{~h}$ and $24 \mathrm{~h}$ was $17 \%$ and $26 \%$, respectively. The X-ray diffraction (XRD), transmission electron microscope coupled with energy dispersive spectrometer (TEM-EDS), and ${ }^{29} \mathrm{Si}$ magic angle spinning-nuclear magnetic resonance $\left({ }^{29} \mathrm{Si}\right.$ MAS-NMR) results showed that the products of a carbonated $\mathrm{C}_{3} \mathrm{~S}$ paste were amorphous silica $\left(\mathrm{SiO}_{2}\right)$ and calcite crystal. There was no trace of calcium silicate hydrate $(\mathrm{C}-\mathrm{S}-\mathrm{H})$ or other polymorphs of calcium carbonate $\left(\mathrm{CaCO}_{3}\right)$ detected.
\end{abstract}

Keywords: carbonation heat; carbonation curing; $\mathrm{CO}_{2}$ uptake; TEM-EDS; ${ }^{29} \mathrm{Si}$ MAS NMR

\section{Introduction}

There is an increasing interest in the early age carbonation curing of Portland cement in recent years for durability improvement [1,2] and carbon dioxide $\left(\mathrm{CO}_{2}\right)$ utilization [3-7]. Since tricalcium silicate $\left(C_{3} S\right)$ is the major phase in Portland cement, accounting for $50 \%$ by weight, understanding the reaction mechanism of $\mathrm{C}_{3} \mathrm{~S}$ exposed to $\mathrm{CO}_{2}$ activation will be of great importance to promote commercial applications of the technology.

Carbonation reaction is a strong exothermic reaction. The calculated reaction heat for $\mathrm{C}_{3} \mathrm{~S}$ carbonation was about $347.4 \mathrm{~kJ} / \mathrm{mol}$ [8]. It is believed that the rapid strength gain due to carbonation reaction and the formation of carbonation products are attributed to the carbonation reaction heat. However, there is no report on carbonation heat from the carbonation reaction of $C_{3} S$, which is due possibly to a lack of proper testing methods.

In the 1970s, Berger et al. [9-11] had studied the effect of the water to binder ratio, $\mathrm{CO}_{2}$ pressure, and carbonation time on the strength development of $\mathrm{C}_{3} \mathrm{~S}$ mortar. It was found that low-lime calcium silicate hydrate $(\mathrm{C}-\mathrm{S}-\mathrm{H})$ and calcite were the main reaction products. Goto et al. [12] used thermogravimetric analysis (TG), gas phase mass spectroscopy, and X-ray diffraction (XRD) to examine the carbonation products of $\mathrm{C}_{3} \mathrm{~S}$. The results showed that an amorphous calcium silicate hydrocarbonate was generated along with the calcium carbonate $\left(\mathrm{CaCO}_{3}\right)$. Shtepenko et al. [13] used ${ }^{29} \mathrm{Si}$ magic angle spinning-nuclear magnetic resonance $\left({ }^{29} \mathrm{Si}\right.$ MAS-NMR), XRD and a scanning electron 
microscope coupled with an energy dispersive spectrometer (SEM-EDS) to analyze the carbonation of $\beta$-dicalcium silicate $\left(\beta-C_{2} S\right)$, and concluded that polymerized silica, calcite, and aragonite were the main products. Ashraf and Olek [14] believed that Ca-modified silica gel and $\mathrm{CaCO}_{3} \mathrm{crystal}$ were the main products of $\mathrm{C}_{3} \mathrm{~S}$ carbonation. From the above studies, it was indicative that the carbonation products of $\mathrm{C}_{3} \mathrm{~S}$ could be classified into two phases: silica phase and calcium carbonate phase. The forms of silica phase found by different studies could be low-lime $\mathrm{C}-\mathrm{S}-\mathrm{H}$, calcium silicate hydrocarbonate, or polymerized silica $\left(\mathrm{SiO}_{2}\right)$ gel. For the $\mathrm{CaCO}_{3}$ phase, all of the polymorph forms of calcite, aragonite, and vaterite were observed.

There are discrepancies in reports on carbonation products. This can be attributed to a number of reasons. The first one can be the carbonation conditions. For example, the $\mathrm{CO}_{2}$ used in the study of Berger et al. was pure, while in the study of Goto et al., it was 5\% purity. Meanwhile, the gas pressures also play a role. Most of the results were obtained from the carbonation of powder samples. The second reason is the limit of test methods. The XRD method commonly used in the above research is suited for the crystal phase, but is not effective for the non-crystal phase. The ${ }^{29} \mathrm{Si}$ MAS NMR method used in the study of Shtepenko et al. can better explore the structure of silicon phase in amorphous products. The TG method can accurately reveal the detail of carbonation products, especially for the quantity analysis of $\mathrm{CaCO}_{3}$. In the study of Shtepenko et al., the SEM-EDS technique was used to test the $\mathrm{Ca} / \mathrm{Si}$ ratio in the micro-area; however, the space resolution of SEM-EDS is limited. So, the statistic results based on SEM-EDS may have some deviation.

The objective of this paper is to measure the early age carbonation heat of $C_{3} S$ paste and determine the carbonation products of $\mathrm{C}_{3} \mathrm{~S}$ paste by different test methods. A retrofitted micro-calorimeter was used to obtain the data of heat release by injecting $\mathrm{CO}_{2}$ gas into the reaction cell. The transmission electron microscope coupled with energy dispersive spectrometer (TEM-EDS) method, which had a higher spatial resolution [15], was employed for microstructure analysis. Thermogravimetric analysis-derivative thermogravimetric analysis (TG-DTG), XRD, and ${ }^{29}$ Si magic angle spinning-nuclear magnetic resonance $\left({ }^{29} \mathrm{Si}\right.$ MAS-NMR) were also applied to investigate the carbonation products of $\mathrm{C}_{3} \mathrm{~S}$ paste.

\section{Materials and Methods}

$\mathrm{C}_{3} \mathrm{~S}$ was synthesized by method of solid phase sintering [16]. It was prepared using analytical reagent calcium hydroxide $\left(\mathrm{Ca}(\mathrm{OH})_{2}\right)$ and $\mathrm{SiO}_{2}$ with molar ratios of 3:1. The mixtures of $\mathrm{Ca}(\mathrm{OH})_{2}$ and $\mathrm{SiO}_{2}$ were mixed with a ball mill for $8 \mathrm{~h}$ to ensure they were evenly mixed. After that, a small amount of anhydrous ethanol was added to the mixture and compressed into cakes. The sintering processes were implemented as following: the compressed cakes were gradually heated from room temperature to $1000{ }^{\circ} \mathrm{C}$ over a period of $100 \mathrm{~min}$; the temperature was kept at $1000{ }^{\circ} \mathrm{C}$ for $60 \mathrm{~min}$; then, the temperature increased from $1000{ }^{\circ} \mathrm{C}$ to $1550{ }^{\circ} \mathrm{C}$; and was then kept at $1550{ }^{\circ} \mathrm{C}$ for $4 \mathrm{~h}$. The sintering process was repeated as described above, until the content of free-CaO was negligible. The synthesized $C_{3} S$ was ground to powder with a Blaine specific surface area of $380 \mathrm{~m}^{2} \cdot \mathrm{kg}^{-1}$ in a planetary mill (Pulverisette 7 Premium Line, FFRITSCH, Idar-Oberstein, Rhineland-Palatinate, Germany). The polymorph of synthesized $\mathrm{C}_{3} \mathrm{~S}$ is $\mathrm{M}_{3}$, which was determined by XRD [17,18], and its pattern is shown in Figure 1. Its chemical compositions, as determined by X-ray fluorescence (XRF) analysis, are presented in Table 1.

Table 1. Chemical composition of synthesized $C_{3} S$.

\begin{tabular}{cc}
\hline Chemical Composition & Content (\%) \\
\hline $\mathrm{CaO}$ & 73.15 \\
$\mathrm{SiO}_{2}$ & 26.06 \\
Others & 0.79 \\
\hline
\end{tabular}




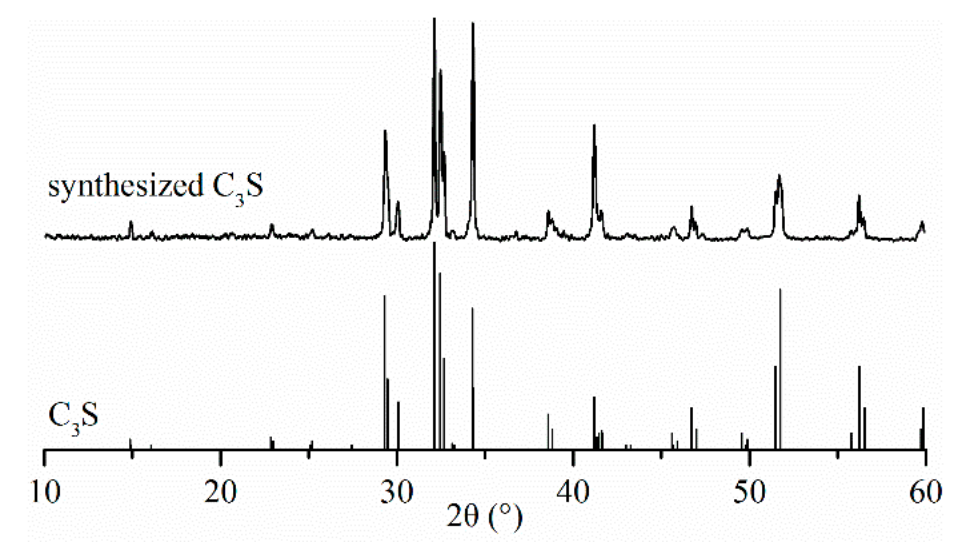

Figure 1. X-ray diffraction (XRD) pattern of synthesized $\mathrm{C}_{3} \mathrm{~S}$.

Heat flow and the amount of released heat during carbonation and hydration were measured using a retrofitted micro-calorimeter (TAM AIR, TA, New Castle, DE, USA). The testing temperature was set at $20^{\circ} \mathrm{C}$. A schematic diagram of the carbonation and hydration reaction heat experimental setup is shown in Figure 2. The $C_{3} S$ paste was prepared by mixing $C_{3} S$ powder and water with a water-to-binder ratio $(\mathrm{w} / \mathrm{b})$ of 0.15 . This ratio has been proved to be optimum by other studies $[7,10,19]$. $\mathrm{A} \mathrm{C}_{3} \mathrm{~S}$ mixture of $5 \mathrm{~g}$ was loaded into an ampoule bottle. For hydration, the sample was sealed immediately and loaded into the micro-calorimeter. A certain amount of water with the same heat capacity was used as the reference sample. For carbonation, an internal mixing suite (an accessory of the micro-calorimeter) was retrofitted to a gas supply unit; $\mathrm{CO}_{2}$ gas could enter into the ampoule through the pipe. A photo of the gas supply unit is shown in Figure 3. Constant temperature was achieved using a thermostatic water bath. Through earlier trials, it was observed that water at $68^{\circ} \mathrm{C}$ could keep the incoming gas at a steady temperature of $20^{\circ} \mathrm{C}$. This ensured that the incoming gas would not affect the micro-calorimetric measurement. The internal pressure of the ampoule bottle was maintained at 0.5 bar to avoid very high pressure, which could lead to the explosion of the ampoule bottle. The data of heat flow and heat were recorded using a calorimeter continuously for $60 \mathrm{~h}$.

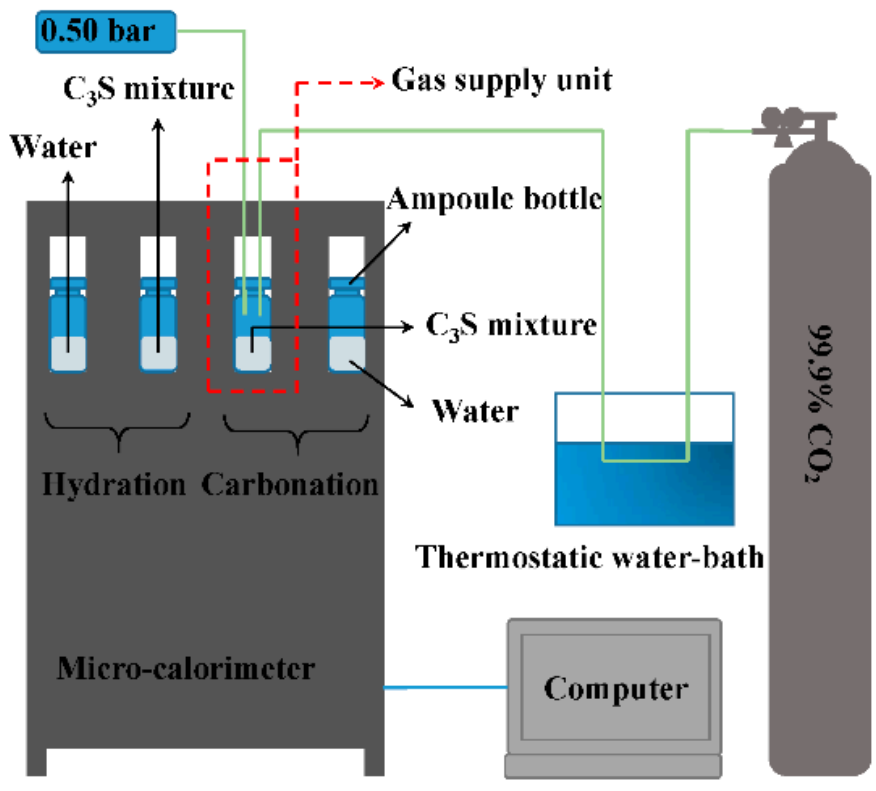

Figure 2. Schematic diagram of carbonation and hydration reaction heat experimental setup. 


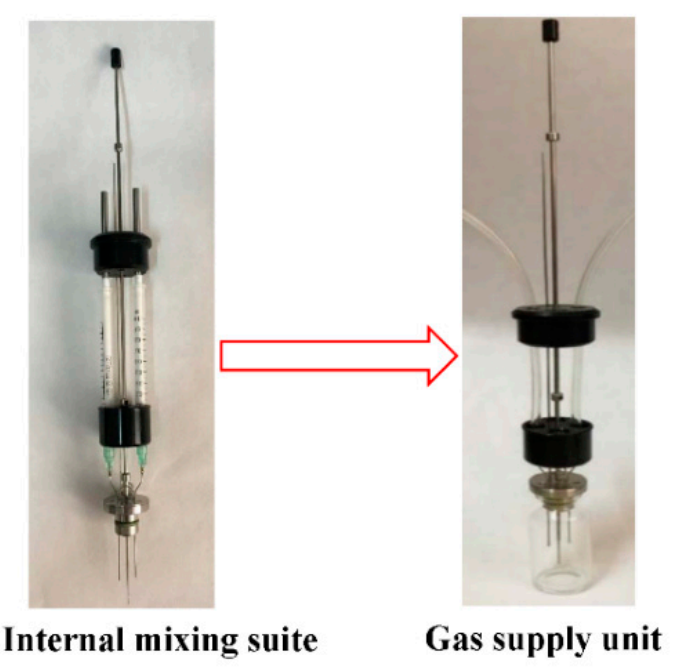

Figure 3. Photo of gas supply unit retrofitted by internal mixing suite.

For the compressive strength test and other micro-analysis tests: $25 \mathrm{~g}$ of $\mathrm{C}_{3} \mathrm{~S}$ mixture with $0.15 \mathrm{w} / \mathrm{b}$ was loaded into a stainless steel mold, and pressed with $8 \mathrm{MPa}$ pressure to make it into a cylindrical sample with the size of $\varphi 20 \times 40 \mathrm{~mm}$. The molding pressure of $8 \mathrm{MPa}$ proved to be the most favorable for carbonation reaction $[19,20]$. The demolded samples were cured following the curing details shown in Table 2. The hydration samples of $\mathrm{H} 2 \mathrm{~h}, \mathrm{H} 24 \mathrm{~h}$, and $\mathrm{H} 28 \mathrm{~d}$ were loaded into a curing chamber immediately. The hydration curing conditions were relative humidity $(\mathrm{RH}) \geq 95 \%$ and $20^{\circ} \mathrm{C}$. Samples of $\mathrm{H} 2 \mathrm{~h}, \mathrm{H} 24 \mathrm{~h}$, and $\mathrm{H} 28 \mathrm{~d}$ were cured for $2 \mathrm{~h}, 24 \mathrm{~h}$, and 28 days, respectively. Figure 4 shows the schematic diagram of a carbonation curing setup. The carbonation curing conditions were as follows: the purity of $\mathrm{CO}_{2}$ was $99.9 \%$; the curing pressure was 4 bar; the test ambient temperature was $20 \pm 3{ }^{\circ} \mathrm{C}$; and $\mathrm{RH} \geq 75 \%$. The carbonation samples were named $\mathrm{C} 2 \mathrm{~h}$ and $\mathrm{C} 24 \mathrm{~h}$, according to the different curing time. In order to determine the maximum possible $\mathrm{CO}_{2}$ uptake of $\mathrm{C}_{3} \mathrm{~S}$ paste under the experimental conditions, a batch of RC (repeated carbonation) was investigated. The samples of RC were directly carbonated for four times without compaction for $24 \mathrm{~h}$. Between different carbonation processes, the sample was ground, dried, and then mixed with water at $0.15 \mathrm{w} / \mathrm{b}$ again. A compressive strength test was then carried out on the samples that were cured to the specified age. The crushed samples were collected and put into anhydrous alcohol to stop the further reaction. Then, the collected crushed samples were further milled, dried at $60{ }^{\circ} \mathrm{C}$, and sealed for TG-DTG, XRD, TEM-EDS, and ${ }^{29} \mathrm{Si}$ MAS NMR tests.

Table 2. Sample number and curing details.

\begin{tabular}{|c|c|c|c|}
\hline Sample Number & Curing Conditions & Sample Form & Curing Age \\
\hline $\mathrm{H} 2 \mathrm{~h}$ & \multirow{3}{*}{ Hydration curing; $\mathrm{RH} \geq 95 \%$; temperature $=20^{\circ} \mathrm{C}$. } & \multirow{6}{*}{ Compact cylinder } & $2 \mathrm{~h}$ \\
\hline $\mathrm{H} 24 \mathrm{~h}$ & & & $24 \mathrm{~h}$ \\
\hline $\mathrm{H} 28 \mathrm{~d}$ & & & 28 days \\
\hline $\mathrm{C} 2 \mathrm{~h}$ & \multirow{3}{*}{$\begin{array}{l}\text { Carbonation curing; purity of } \mathrm{CO}_{2}=99.9 \% \text {; } \\
\text { curing pressure }=4 \text { bar; } \mathrm{RH} \geq 75 \% \text {; temperature }=20 \pm 3{ }^{\circ} \mathrm{C} \text {. }\end{array}$} & & $2 \mathrm{~h}$ \\
\hline $\mathrm{C} 24 \mathrm{~h}$ & & & $24 \mathrm{~h}$ \\
\hline $\mathrm{RC}$ & & & $24 \mathrm{~h} \times 4$ times \\
\hline
\end{tabular}




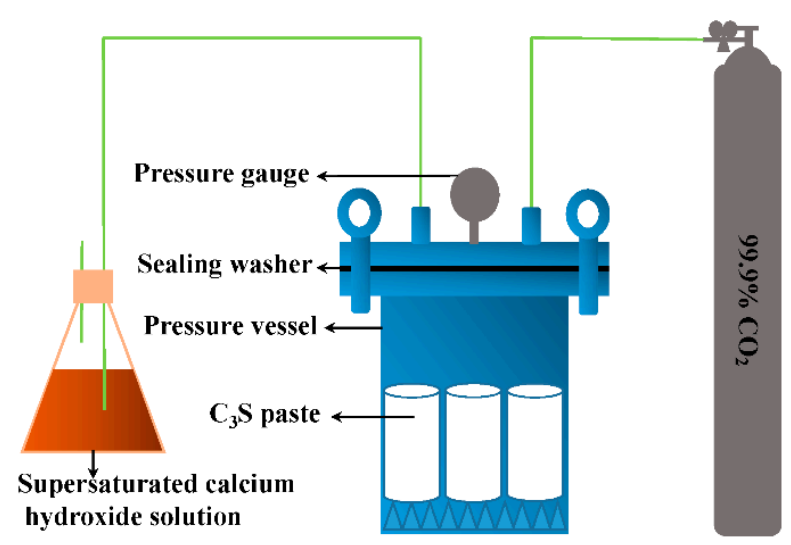

Figure 4. Schematic diagram of the carbonation curing setup.

The theoretical $\mathrm{CO}_{2}$ uptake is calculated by Steinour's equation, as shown in Equation (1). Since $\mathrm{C}_{3} \mathrm{~S}$ was a pure phase without influence by $\mathrm{SO}_{3}, \mathrm{Na}_{2} \mathrm{O}$, and $\mathrm{K}_{2} \mathrm{O}$, the $\mathrm{CO}_{2}$ uptake capacity was calculated by $\mathrm{CaO}$ content, which was determined by XRF. The experimental $\mathrm{CO}_{2}$ uptake is calculated by TG data, the calculation equation is shown in Equation (2). In Equation (2), the sample weight is the total weight of the tested samples. The total weight loss is the loss of samples from room temperature to $1000{ }^{\circ} \mathrm{C}$. The weight loss of decarbonation is the mass loss between 500 and $1000{ }^{\circ} \mathrm{C}$. The carbonation degree of the sample is calculated using Equation (3):

$$
\begin{gathered}
\text { Theoretical } \mathrm{CO}_{2} \text { uptake }(\%)=0.785\left(\mathrm{CaO}-0.7 \mathrm{SO}_{3}\right)+1.09 \mathrm{Na}_{2} \mathrm{O}+0.93 \mathrm{~K}_{2} \mathrm{O} \text {, } \\
\text { Experimental } \mathrm{CO}_{2} \text { uptake }(\%)=(\text { weight loss of decarbonation }) / \\
\text { (sample weight }- \text { total weight loss }) \times 100 \%,
\end{gathered}
$$

Carbonation degree $(\%)=\left(\right.$ experimental $\mathrm{CO}_{2}$ uptake $) /\left(\right.$ theoretical $\mathrm{CO}_{2}$ uptake $) \times 100 \%$.

Q600 (TA, New Castle, DE, USA) was used to obtain the TG-DTG results; the range of the machine was $200 \mathrm{mg}$. The weight of the tested sample was about $30 \mathrm{mg}$. The heating rate was $10^{\circ} \mathrm{C} / \mathrm{min}$ from room temperature to the final $100{ }^{\circ} \mathrm{C} . \mathrm{N}_{2}$ was adopted as the protecting gas with a flow rate of $100 \mathrm{~mL} / \mathrm{min}$. A D8 ADVANCE (Bruker, Karlsruhe, Baden-Wurttemberg, Germany) with a Cu K $\alpha$ target, a scanning range of $15-55^{\circ}$, and a scanning speed of $2^{\circ} / \mathrm{min}$ was utilized for the XRD test. The TEM-EDS result was tested by Tecnai G2 F30 transmission electron microscope (FEI, Hillsborough, OR, USA) and its attached energy dispersive spectrometer. ${ }^{29} \mathrm{Si}$ MAS NMR experiments were performed using a AVANCE III 600 spectrometer (Bruker, Karlsruhe, Baden-Wurttemberg, Germany) at a resonance frequency of $119.2 \mathrm{MHz}$. The spectra was recorded on a 4-mm probe with a spinning rate of $10 \mathrm{kHz}$, a $\pi / 4$ pulse length of $2.6 \mu \mathrm{s}$, and a recycle delay of $80 \mathrm{~s}$. The chemical shifts of ${ }^{29} \mathrm{Si}$ was referenced to tetramethylsilane.

\section{Results}

\subsection{Carbonation Reaction Heat}

Figure 5 shows the heat flow of carbonation and hydration versus time. From the partially enlarged detail, it can be seen that the heat flow increased significantly at the moment of the injection of $\mathrm{CO}_{2}$, and reached the peak in a few minutes. This suggested that the carbonation reaction of $\mathrm{C}_{3} \mathrm{~S}$ paste occurs immediately upon the exposure to the carbon dioxide gas under the conditions of $0.15 \mathrm{w} / \mathrm{b}$, 0.5 bar pressure, and $99.9 \%$ purity of $\mathrm{CO}_{2}$. It was observed that the peak value of carbonation heat flow was up to $0.54 \mathrm{~W} / \mathrm{g}$, after which it fell rapidly in approximately 10 minutes, and continued to fall gradually to a lower value. The reason for the decrease in heat flow could be the lack of water. This was evident by a large amount of condensed water on the wall of the ampule bottle after the test. 
For the partially enlarged detail of the hydration curve, it was seen that the heat flow increased very slowly. It took approximately $15 \mathrm{~h}$ to reach the peak. The maximum heat flow of hydration was less than $1 \%$ in comparison to that generated by carbonation.

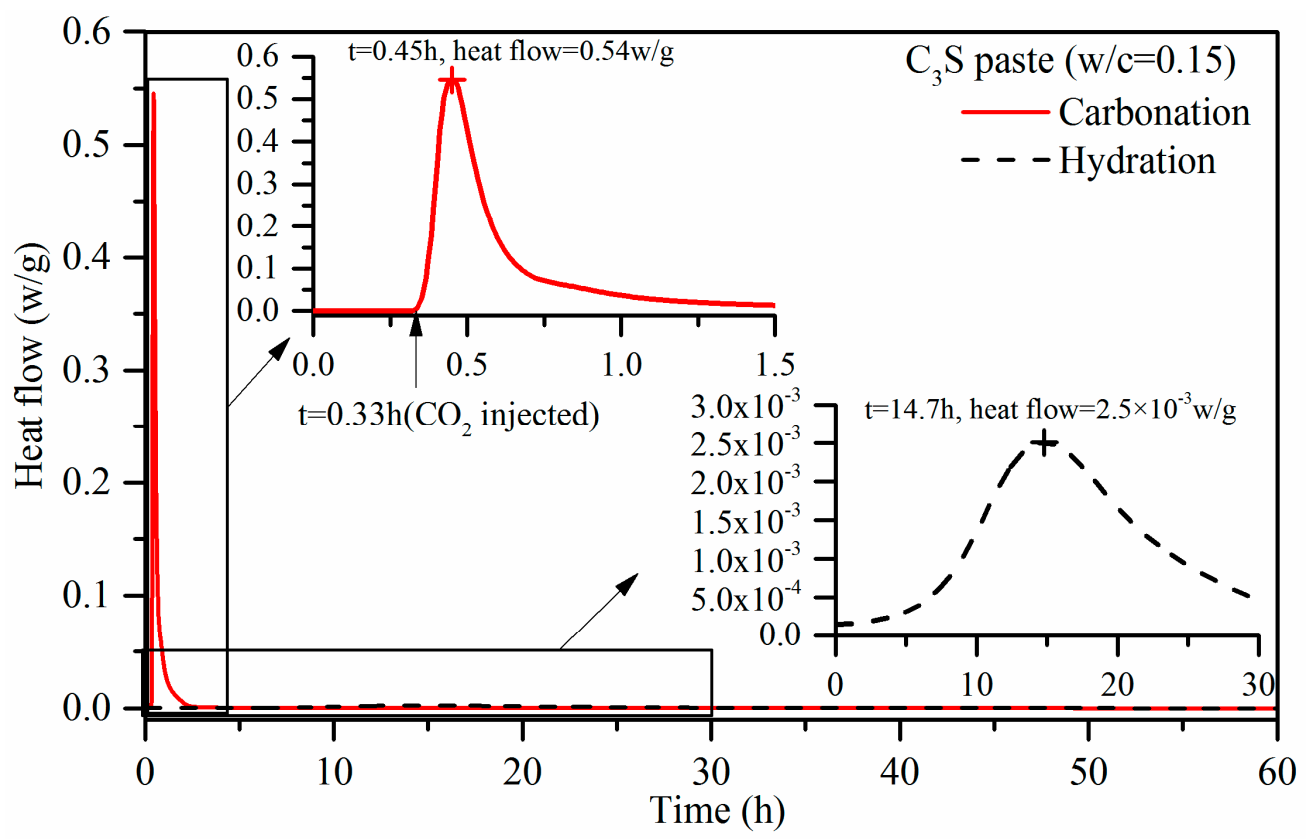

Figure 5. Heat flow of carbonation and hydration versus time.

Figure 6 shows the heat of carbonation and hydration versus time. Due to the higher heat flow, the heat rapidly reached a high value in the carbonation sample. In $60 \mathrm{~h}$, the carbonation heat of $\mathrm{C}_{3} \mathrm{~S}$ was up to $116.7 \mathrm{~kJ} / \mathrm{mol}$. Although the heat release for hydration took longer, the hydration heat of hydration was only $32.4 \mathrm{~kJ} / \mathrm{mol}$, which is about one third that of carbonation.

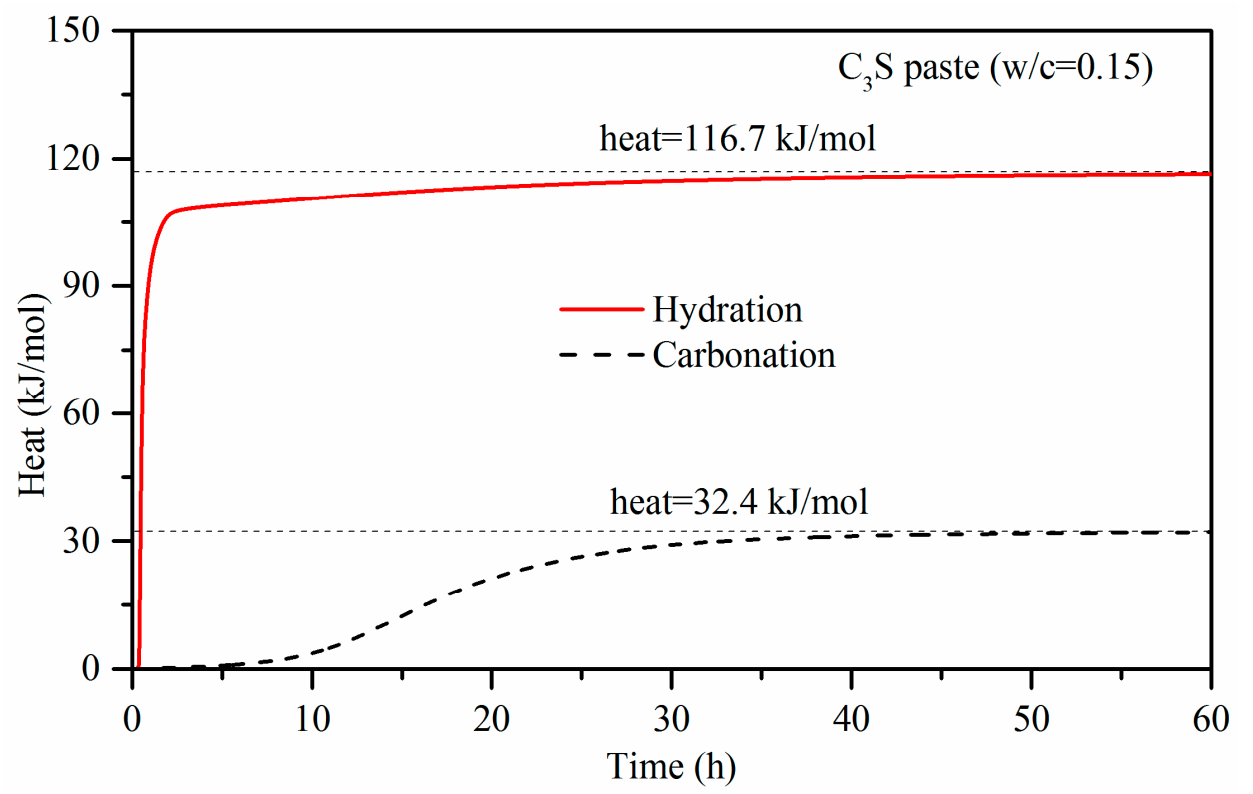

Figure 6. Heat of carbonation and hydration versus time. 


\subsection{Compressive Strength}

The compressive strengths of the carbonation and hydration $\mathrm{C}_{3} \mathrm{~S}$ pastes are shown in Figure 7. It was seen that the compressive strength of the $\mathrm{C}_{3} \mathrm{~S}$ paste reached $27.5 \mathrm{MPa}$ after $2 \mathrm{~h}$ of carbonation. In comparison, the hydration reference sample had shown a strength of $5.2 \mathrm{MPa}$, which was attributed to the compression molding instead of the hydration reaction. The compressive strength of the $\mathrm{C}_{3} \mathrm{~S}$ paste carbonated for $24 \mathrm{~h}(\mathrm{C} 24 \mathrm{~h})$ reached $62.9 \mathrm{MPa}$. Meanwhile, the compressive strength of $\mathrm{H} 24 \mathrm{~h}$, which hydrated for $24 \mathrm{~h}$, was only $8.6 \mathrm{MPa}$, which was much lower than that of the carbonated sample. The strength of $\mathrm{C} 24 \mathrm{~h}$ was even higher than that of the samples hydrated for 28 days (H28d), which was $56.9 \mathrm{MPa}$. The comparison of $\mathrm{C} 2 \mathrm{~h}$ and $\mathrm{C} 24 \mathrm{~h}$ showed that the strength gain was proportional to the carbonation time. The early carbonation of $\mathrm{C}_{3} \mathrm{~S}$ is an accelerated reaction process due to the rapid gain in strength. Therefore, the carbonation curing can be used to shorten the production cycle and gain economic benefits.

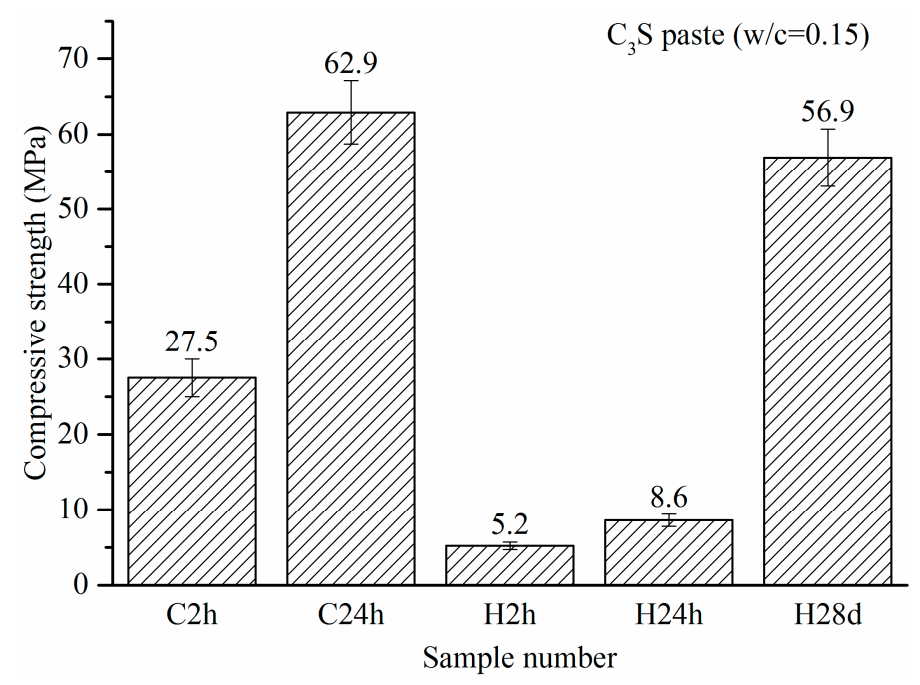

Figure 7. Compressive strengths of carbonation and hydration $\mathrm{C}_{3} S$ pastes.

\subsection{Carbonation Depth}

Pictures of cracked samples sprayed with alcohol phenolphthalein solution are presented in Figure 8. The hydration sample turned red because of the alkaline $\mathrm{Ca}(\mathrm{OH})_{2}$ that was generated by the hydration reaction. The carbonation sample was colorless throughout entire cross-section, suggesting that carbonation had penetrated to the entire specimen in $2 \mathrm{~h}$.

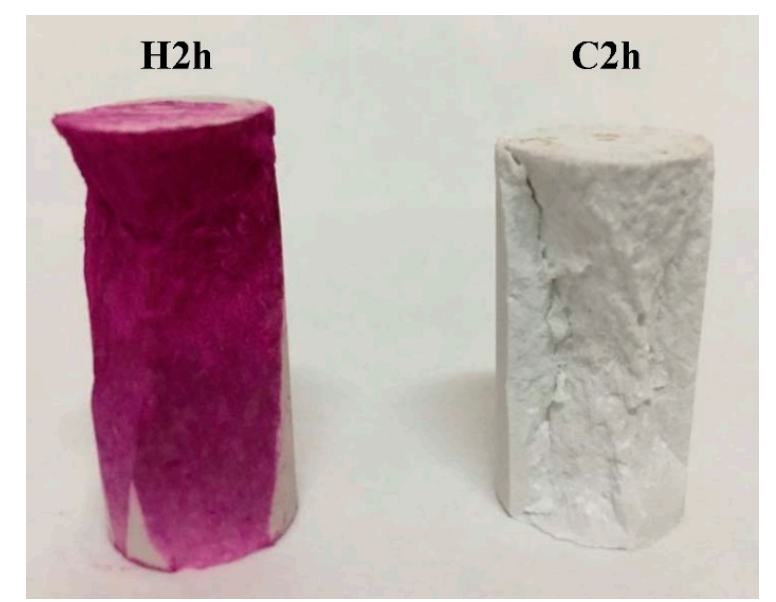

Figure 8. Samples sprayed by an alcohol phenolphthalein solution. 


\subsection{TG-DTG}

The TG-DTG curves of carbonation and hydration samples are shown in Figure 9. The weight loss before $105^{\circ} \mathrm{C}$ was due to the evaporation of free water. The weight loss between $105{ }^{\circ} \mathrm{C}$ and $300{ }^{\circ} \mathrm{C}$ was due to the dehydration of $\mathrm{C}-\mathrm{S}-\mathrm{H}$. The weight loss between $300-500{ }^{\circ} \mathrm{C}$ was caused by dehydroxylation. In this study, the main reason was the dehydroxylation of $\mathrm{Ca}(\mathrm{OH})_{2}$. The weight loss above $500{ }^{\circ} \mathrm{C}$ was due to the decomposition of $\mathrm{CaCO}_{3}$ [21-23]. In the dehydration temperature range of C-S-H $\left(105-300^{\circ} \mathrm{C}\right)$, the weight loss of the three hydration batches was obvious. The weight loss increased with the hydration time, suggesting that the longer the hydration time, the greater amount of $\mathrm{C}-\mathrm{S}-\mathrm{H}$. However, for carbonation batches in the same temperature range $\left(105-300^{\circ} \mathrm{C}\right)$, there was almost no C-S-H due to the low weight loss shown in Figure 9. The peak of weight loss for $\mathrm{Ca}(\mathrm{OH})_{2}$ dehydroxylation was obvious at about $400{ }^{\circ} \mathrm{C}$ in the hydration sample. However, the peak did not exist in the carbonation sample in the same range. The peak of weight loss due to $\mathrm{CaCO}_{3}$ decomposition was observed obviously in carbonation samples. The TG curves showed that the weight loss increased with the increase of the carbonation time in the carbonation samples. Since the batch of RC had been added with water and repeatedly carbonized, its degree of reaction was highest. Hence, the weight loss of RC was greatest. This indicated that in addition to the short carbonation time, the lack of water was the other factor limiting further carbonation. From the DTG curve, it was seen that the peak temperature of the decomposition of $\mathrm{CaCO}_{3}$ increased with the increase of carbonation; most of the $\mathrm{CaCO}_{3}$ decomposed after $750{ }^{\circ} \mathrm{C}$, especially in the $\mathrm{RC}$ sample. This was related to the amount of $\mathrm{CaCO}_{3}$ and the degree of crystallization. The greater the amount of $\mathrm{CaCO}_{3}$ and the higher degree of crystallization, the higher the decomposition temperature.

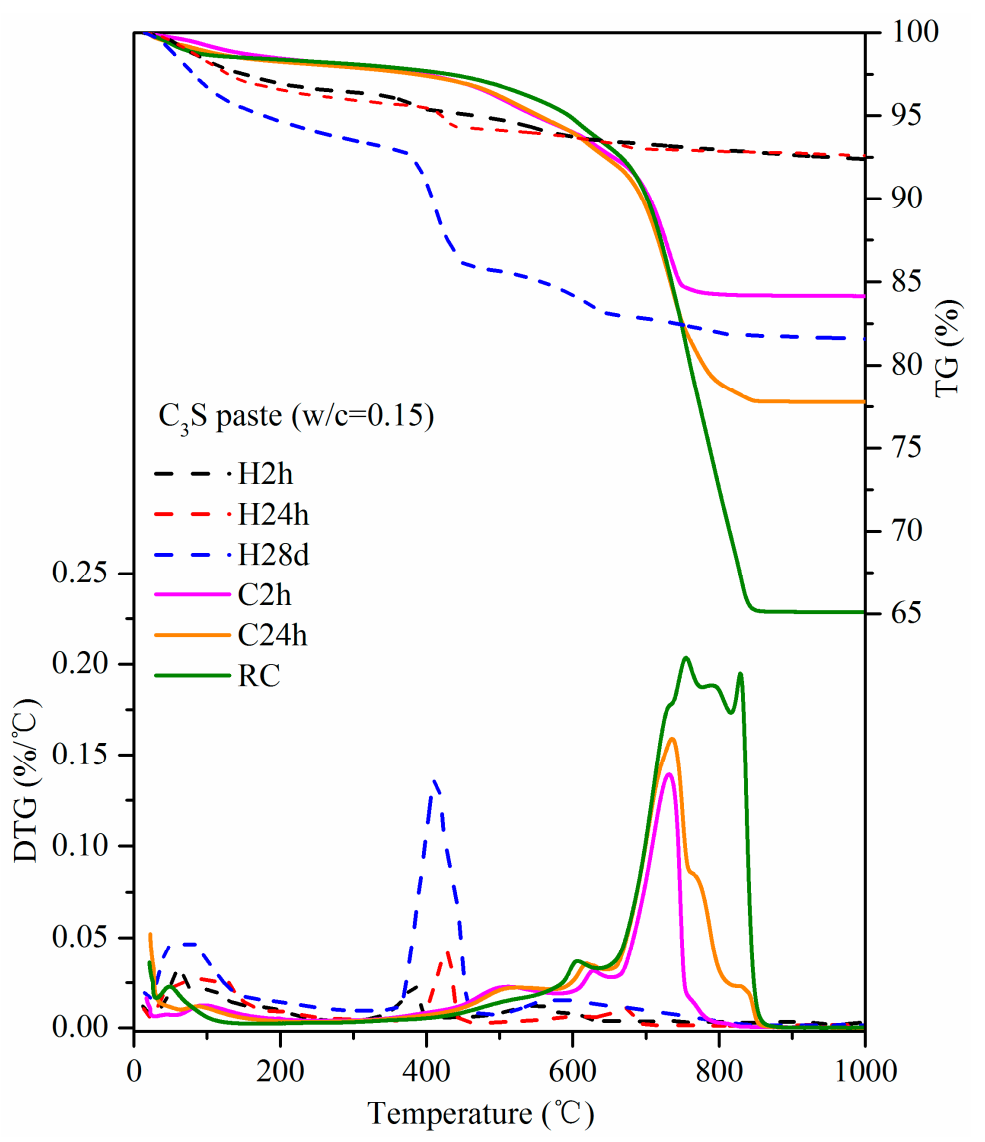

Figure 9. Thermogravimetric analysis-derivative thermogravimetric analysis (TG-DTG) curves of carbonation and hydration samples. 
The results regarding weight loss, $\mathrm{CO}_{2}$ uptake, and carbonation degree are shown in Table 3. The $\mathrm{CO}_{2}$ uptake of $\mathrm{C} 2 \mathrm{~h}$ and $\mathrm{C} 24 \mathrm{~h}$ was $17.17 \%$ and $26.32 \%$, respectively. The observation of $\mathrm{CO}_{2}$ uptake increased with the increase of carbonation time, which was consistent with the conclusions of other studies [5-7]. The $\mathrm{CO}_{2}$ uptake of $\mathrm{RC}$ had reached 51.11\%. Although it was of little significance for practical use, the results revealed the maximum possible $\mathrm{CO}_{2}$ uptake capacity of the $\mathrm{C}_{3} \mathrm{~S}$ paste exposed to $\mathrm{CO}_{2}$.

Table 3. Weight loss, $\mathrm{CO}_{2}$ uptake, and carbonation degree of carbonation samples calculated by TG-DTG data.

\begin{tabular}{cccccc}
\hline \multirow{2}{*}{ Sample Number } & \multicolumn{2}{c}{ Weight Loss (\%) } & \multicolumn{2}{c}{$\mathrm{CO}_{\mathbf{2}}$ Uptake (\%) } & \multirow{2}{*}{ Carbonation Degree (\%) } \\
\cline { 2 - 4 } & Decarbonation & Total & Experimental & Theoretical & \\
\hline C2h & 14.21 & 15.85 & 17.17 & & 29.71 \\
C24h & 20.47 & 22.22 & 26.32 & 57.84 & 45.53 \\
RC & 31.28 & 34.89 & 51.11 & & 88.43 \\
\hline
\end{tabular}

\subsection{XRD}

XRD test was carried out to identify the crystalline phase in the product. The XRD patterns are shown in Figure 10. The result showed that the unreacted $\mathrm{C}_{3} \mathrm{~S}$ and $\mathrm{Ca}(\mathrm{OH})_{2}$ were the main crystalline phases in the hydration sample. While in the carbonation samples, $\mathrm{CaCO}_{3}$ and unreacted $\mathrm{C}_{3} \mathrm{~S}$ were the main crystalline phases. No other polymorphs appeared, except for calcite in the carbonation sample. The intensity of the calcite diffraction peak increased, while that of the $C_{3} S$ decreased with the prolonged carbonation time. This suggested that the carbonation process consumed $\mathrm{C}_{3} \mathrm{~S}$ and simultaneously generated calcite. The diffraction peak of $C_{3} S$ in $R C$ was very weak, but the peak of calcite was very high. This showed that the carbonation degree of RC was high. The degree of carbonation reaction reflected by the XRD results was consistent with TG-DTG.

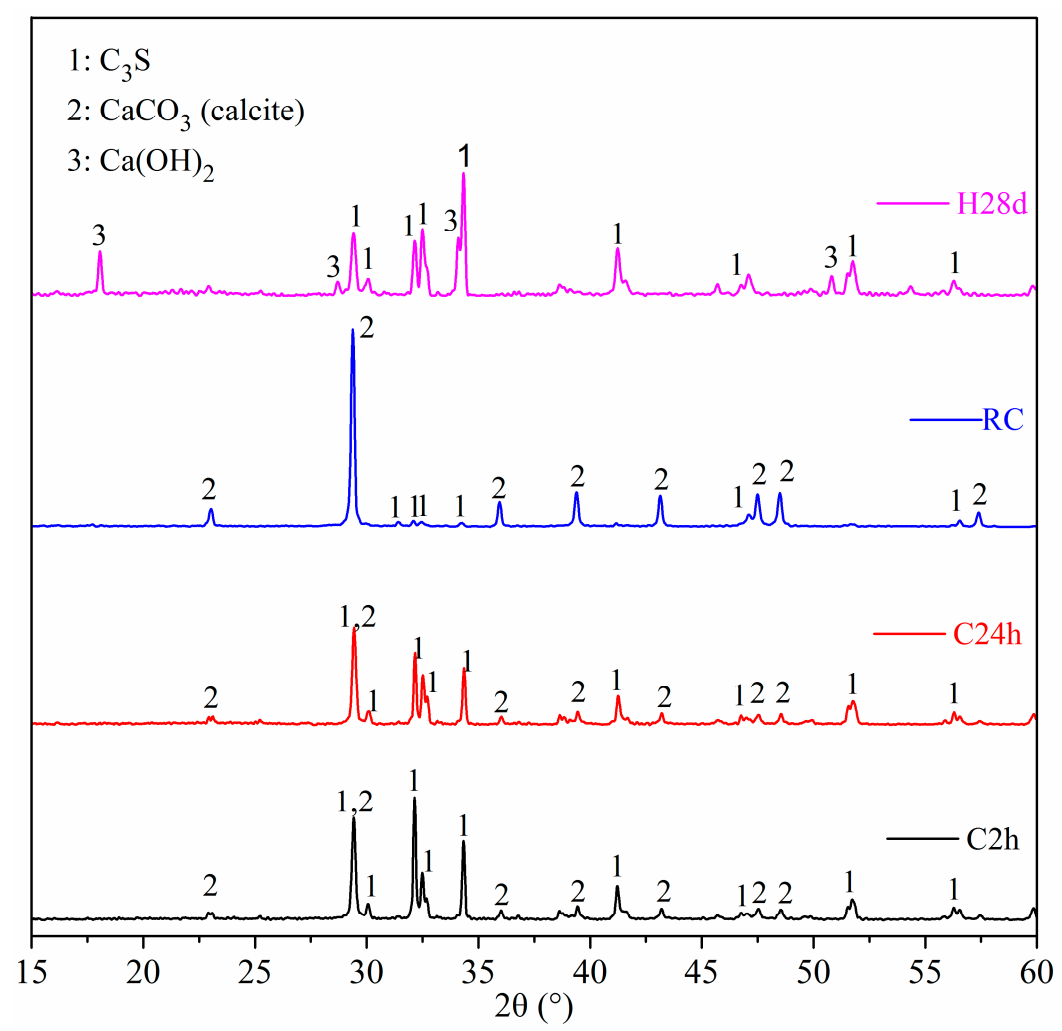

Figure 10. XRD pattern of carbonation and hydration samples. 


\subsection{TEM-EDS}

Figure 11 is a TEM image and energy dispersive spectrum (EDS) mappings of C2h. According to the morphology of phase, there were mainly three phases: a cloud phase (Spot 1), a crystal phase (Spot 2) and a darker lump phase (Spot 3). The atomic Si:O in the cloud phase was close to 1:2. The diffraction peaks of $\mathrm{Si}$ were not found in the former XRD result, suggesting that the cloud phase was amorphous silica [24,25]. The EDS results showed that there was no $\mathrm{Si}$ in the crystal phase, confirming that the crystal phase was $\mathrm{CaCO}_{3}$. The dark lump was unreacted $\mathrm{C}_{3} \mathrm{~S}$, which was confirmed by the EDS result of $\mathrm{Ca}: \mathrm{Si}$, which had an atomic ratio close to 3:1. Figure 12 shows a high-resolution TEM (HRTEM) image and a selected area Fourier transform image of $\mathrm{C} 2 \mathrm{~h}$. The diffraction rings in A and the diffraction lattice in $\mathrm{B}$ were respectively correspondent with the amorphous $\mathrm{SiO}_{2}$ and crystal $\mathrm{CaCO}_{3}$. It was also observed that the amorphous $\mathrm{SiO}_{2}$ was close to the crystal $\mathrm{CaCO}_{3}$, and had a clear interface.

A TEM image and EDS mappings of C24h are also present in Figure 13. The HRTEM image and selected area Fourier transform images of $\mathrm{C} 24 \mathrm{~h}$ are presented in Figure 14. The C24h sample had no new phase compared with $\mathrm{C} 2 \mathrm{~h}$, according to the phase morphology in Figure 11. It was difficult to find the relative content difference of the product phases due to the small visual field. The figures also show that the microstructures in nanoscale were similar at $2 \mathrm{~h}$ and $24 \mathrm{~h}$ of carbonation, although the latter produced higher strength and higher $\mathrm{CO}_{2}$ uptake, which were also evident by the TG-DTG and XRD results.

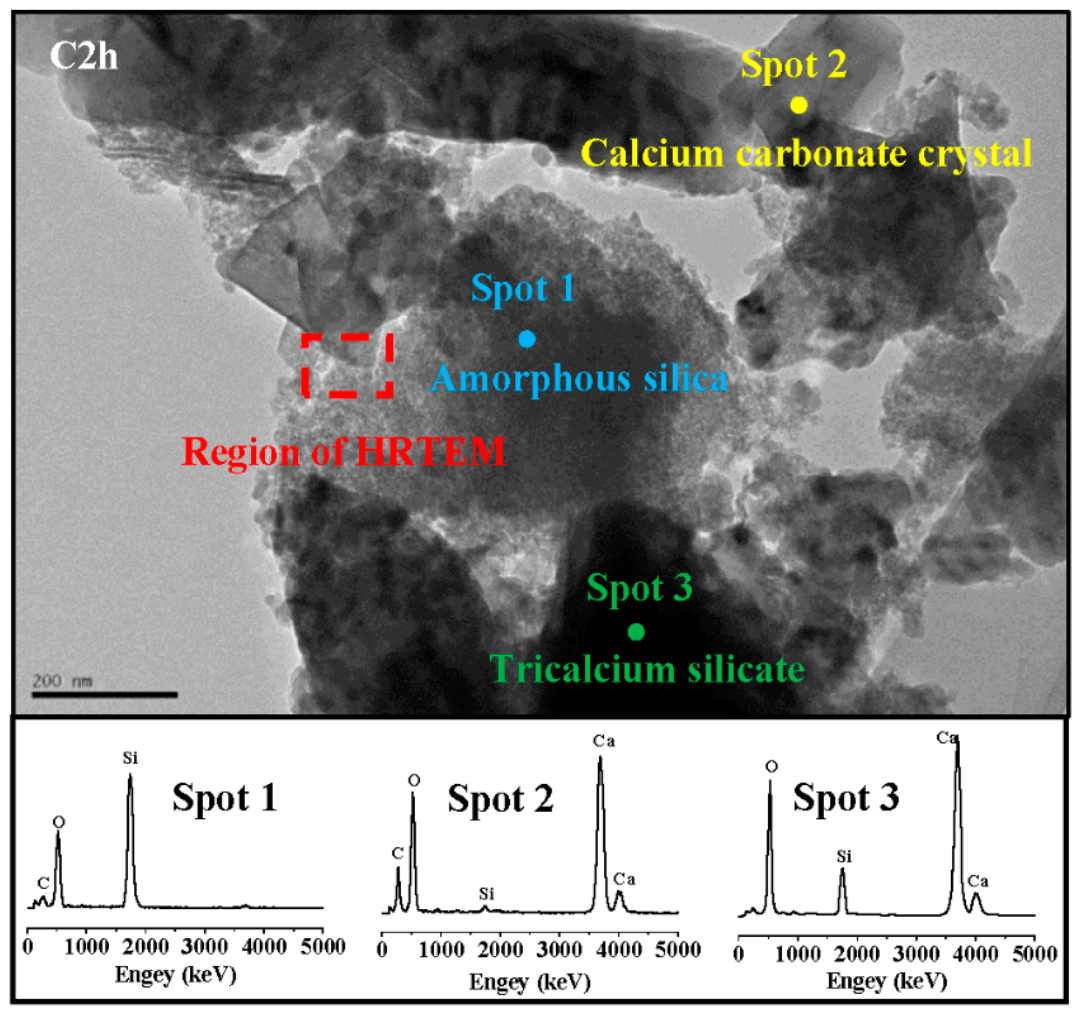

Figure 11. Transmission electron microscope (TEM) image and EDS mappings of C2h.

\section{7. ${ }^{29}$ Si MAS NMR}

The ${ }^{29}$ Si MAS NMR spectra of different samples are shown in Figure 15. The resonance in this figure was divided into five ranges: -65 to $-75 \mathrm{ppm}$ belonged to $\mathrm{Q}^{0}$; near $-80 \mathrm{ppm}$ belonged to $\mathrm{Q}^{1}$; near $-85 \mathrm{ppm}$ belonged to $\mathrm{Q}^{2}$; near $-100 \mathrm{ppm}$ belonged to $\mathrm{Q}^{3}$; and near $-110 \mathrm{ppm}$ belonged to $\mathrm{Q}^{4}$ [26-28]. The resonance peak of $\mathrm{Q}^{0}$ originated from silicate monomer, and in this study, it came from unreacted $C_{3} S$. The resonance peaks of $Q^{1}$ and $Q^{2}$ originated from the end and middle of the 
C-S-H chain structure. The resonance peaks of $\mathrm{Q}^{3}$ and $\mathrm{Q}^{4}$ originated from the chain-branching sites and three-dimensional cross-linked framework [29], respectively. These peaks came from amorphous $\mathrm{SiO}_{2}$ in this study.

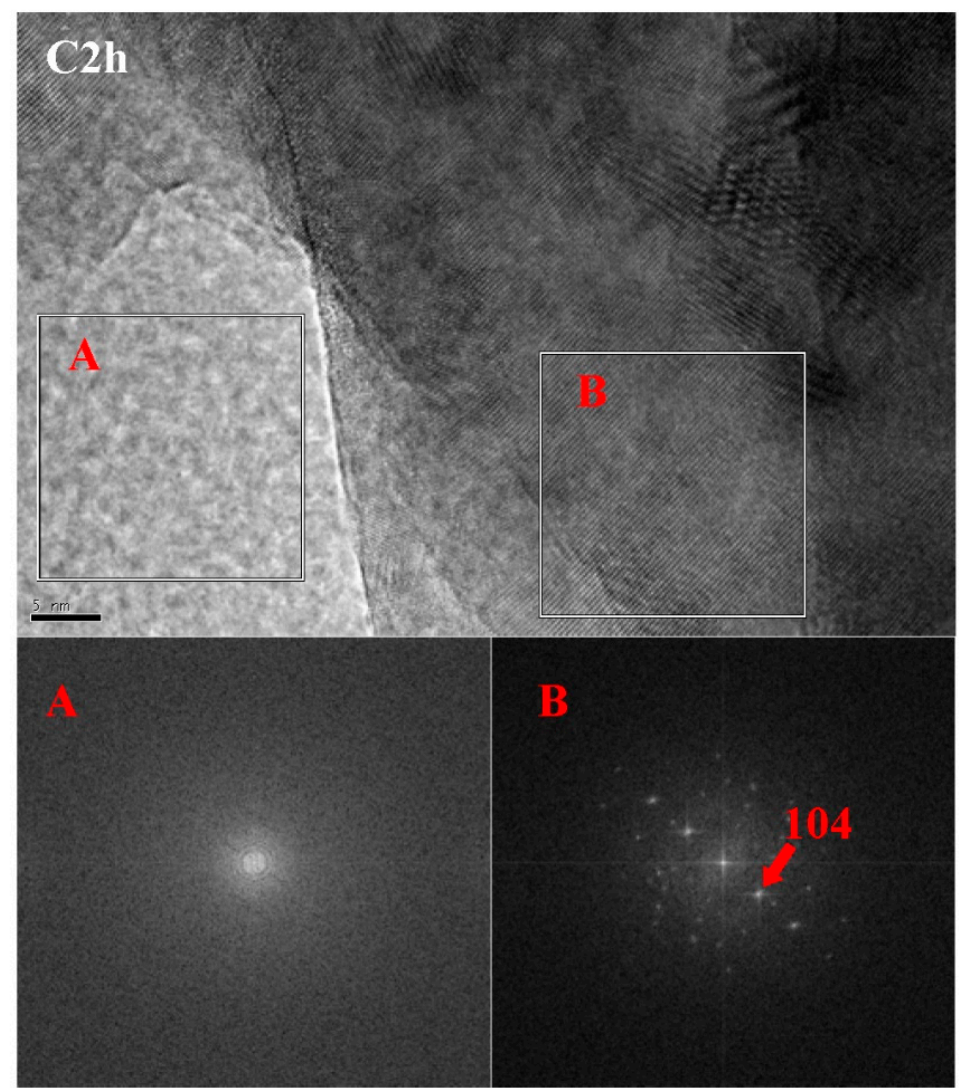

Figure 12. High-resolution TEM (HRTEM) image and selected area Fourier transform images of C2h.

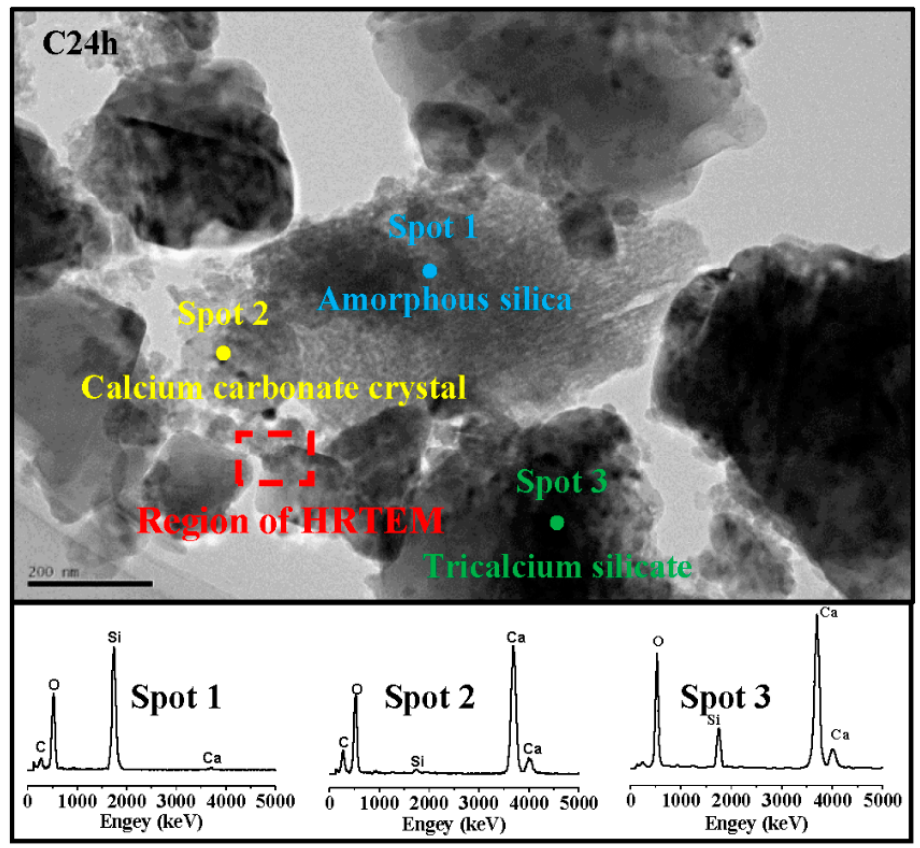

Figure 13. TEM image and EDS mappings of C24h. 


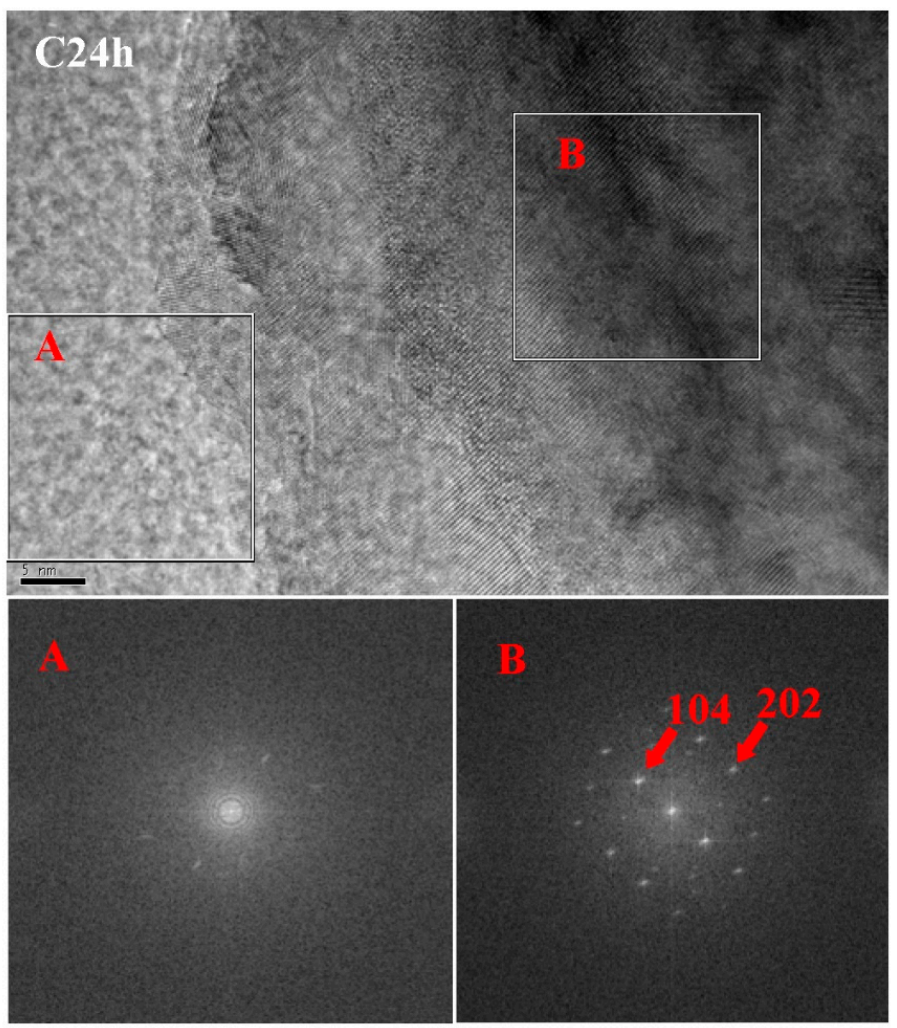

Figure 14. HRTEM image and selected area Fourier transform images of C24h.

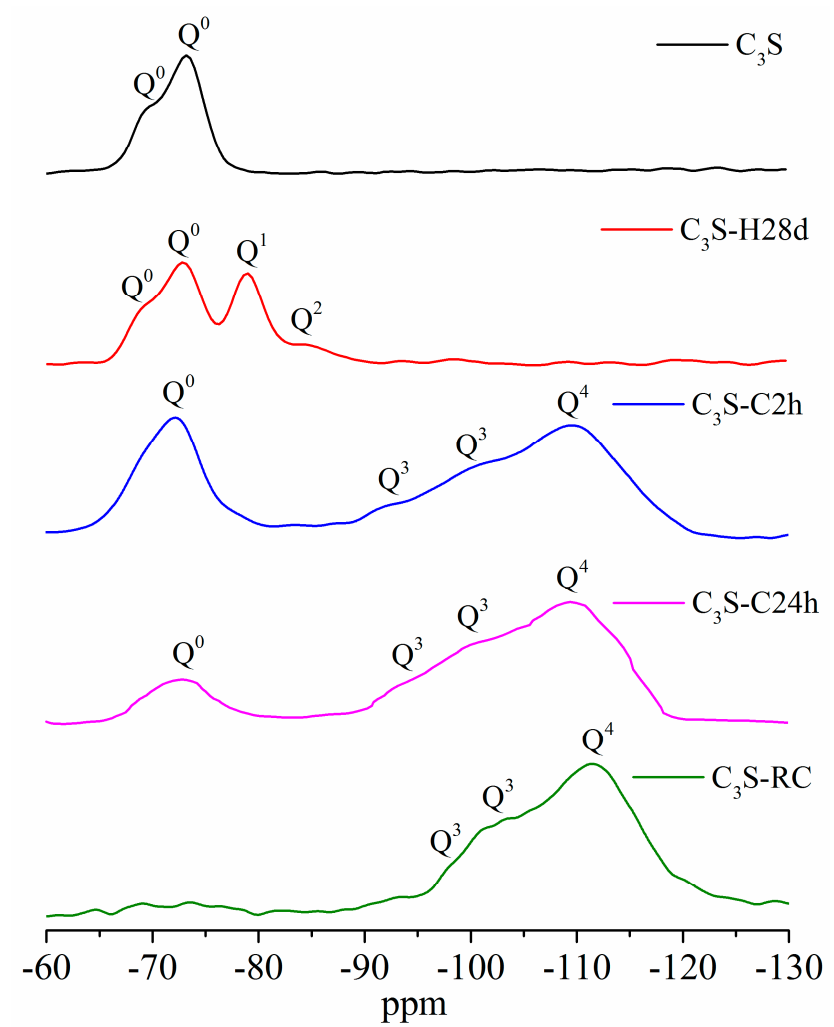

Figure 15. ${ }^{29} \mathrm{Si}$ magic angle spinning-nuclear magnetic resonance (MAS-NMR) pattern of different samples. 
There were only $\mathrm{Q}^{0}$ resonance peaks in the sample of synthesized $\mathrm{C}_{3} \mathrm{~S}$. After 28 days of hydration, the intensity of $\mathrm{Q}^{0}$ decreased, while the intensity of the $\mathrm{Q}^{1}$ and $\mathrm{Q}^{2}$ that originated from $\mathrm{C}-\mathrm{S}-\mathrm{H}$ increased simultaneously. The carbonation samples mainly had the resonance peaks of $\mathrm{Q}^{0}$ of unreacted $\mathrm{C}_{3} \mathrm{~S}$, and $\mathrm{Q}^{3}$ and $\mathrm{Q}^{4}$ of amorphous $\mathrm{SiO}_{2}$. No resonance peaks of $\mathrm{Q}^{1}$ and $\mathrm{Q}^{2}$ from $\mathrm{C}-\mathrm{S}-\mathrm{H}$ appeared in carbonation samples. It showed that there was few or no $\mathrm{C}-\mathrm{S}-\mathrm{H}$ in carbonation samples. The intensity of $Q^{0}$ decreased with the progress of carbonation. It showed that unreacted $C_{3} S$ reduced as carbonation time increased. This result was consistent with XRD. The intensity of $\mathrm{Q}^{3}$ and $\mathrm{Q}^{4}$ increased with the increase of carbonization time. At the same time, $\mathrm{Q}^{3}$ had the tendency to transform into $\mathrm{Q}^{4}$.

\section{Discussion}

The experimental carbonation heat of $\mathrm{C}_{3} \mathrm{~S}$ was $116.7 \mathrm{~kJ} / \mathrm{mol}$, which was measured by microcalorimeter, and is lower than the calculation value $347.4 \mathrm{~kJ} / \mathrm{mol}$ in the research of Goodbrake et al. [8]. As mentioned in the former text, the lack of water inhibited the carbonation reaction. The main reason for the experimental carbonation heat being lower than the calculation value is the incomplete carbonation reaction.

The results of reaction heat and TG-DTG show that the rate and degree of the carbonation reaction were higher than those of the hydration reaction. The high heat flow increased the reaction temperature in a short time, and the hydrolysis of $\mathrm{C}_{3} \mathrm{~S}$ and the speed of the diffusion of calcium ions were both accelerated by the high reaction temperature. Compared with the hydration of $\mathrm{C}_{3} S$ paste, the formation of $\mathrm{Ca}(\mathrm{OH})_{2}$ was substituted by $\mathrm{CaCO}_{3}$ in the carbonation reaction. Due to the low solubility of $\mathrm{CaCO}_{3}$, more calcium ions were dissolved from $\mathrm{C}_{3} \mathrm{~S}$, and the extent of the reaction increased. In addition, the high reaction heat influenced the product. Only calcite existed in the products, and no traces of aragonite and vaterite were detected. It is probably due to the high reaction heat, since calcite is the most stable phase among the three polymorphs of $\mathrm{CaCO}_{3}$ under high temperature [30].

The TG-DTG, TEM-EDS, and ${ }^{29} \mathrm{Si}$ MAS NMR results showed that there was only amorphous $\mathrm{SiO}_{2}$ and crystal $\mathrm{CaCO}_{3}$ in the carbonation products. The silicate phases reported by other researchers, such as C-S-H [9-11], calcium silicate hydrocarbonate [12], or Ca-modified silica gel [14], were not found in this study. Figure 16 shows the molecular structure of $\mathrm{C}_{3} \mathrm{~S}, \mathrm{C}-\mathrm{S}-\mathrm{H}$, amorphous $\mathrm{SiO}_{2}$, and different $\mathrm{Q}^{\mathrm{n}}$ in their structure. It can be seen from the figure that the $\mathrm{Si}$ in $\mathrm{C}_{3} \mathrm{~S}$ belongs to $\mathrm{Q}^{0} ; \mathrm{Q}^{1}$ and $\mathrm{Q}^{2}$ exist in $\mathrm{C}-\mathrm{S}-\mathrm{H}$; and $\mathrm{Q}^{3}$ and $\mathrm{Q}^{4}$ exist in amorphous $\mathrm{SiO}_{2}$. From the perspective of the molecular structure, the cohesive force of $\mathrm{C}-\mathrm{S}-\mathrm{H}$ originated from the Van der Waals force and Coulomb force [31-33]. However, for amorphous $\mathrm{SiO}_{2}$, there is a three-dimensional network structure, leading to a $\mathrm{Si}-\mathrm{O}$ bond for a higher bonding force. Hence, the amorphous $\mathrm{SiO}_{2}$ has a higher cohesive force than $\mathrm{C}-\mathrm{S}-\mathrm{H}$.

Figure 17 is a schematic diagram of the microstructure formation of $\mathrm{C}_{3} \mathrm{~S}$ paste hydration and carbonation, which is based on former TEM-EDS results and other research results [34-36]. The main products of the hydration of $\mathrm{C}_{3} \mathrm{~S}$ pastes are $\mathrm{C}-\mathrm{S}-\mathrm{H}$ and calcium hydroxide crystals. With the progress of a hydration reaction, the unreacted particles of $C_{3} S$ become smaller, while more hydration products develop [37]. Similar to the process of hydration, with the carbonation reaction proceeding, the size of the $\mathrm{C}_{3} \mathrm{~S}$ particle decreases, while that of the carbonation products increases. The $\mathrm{CaCO}_{3}$ crystals that acted as a skeleton, and the amorphous $\mathrm{SiO}_{2}$ that acted as a matrix filling in the voids formed a dense structure, which significantly enhanced the strength. Compared with the hydration process, the carbonation reaction process is more rapid, and the reaction degree is higher. Therefore, the carbonation reaction is an accelerated hardening process. 


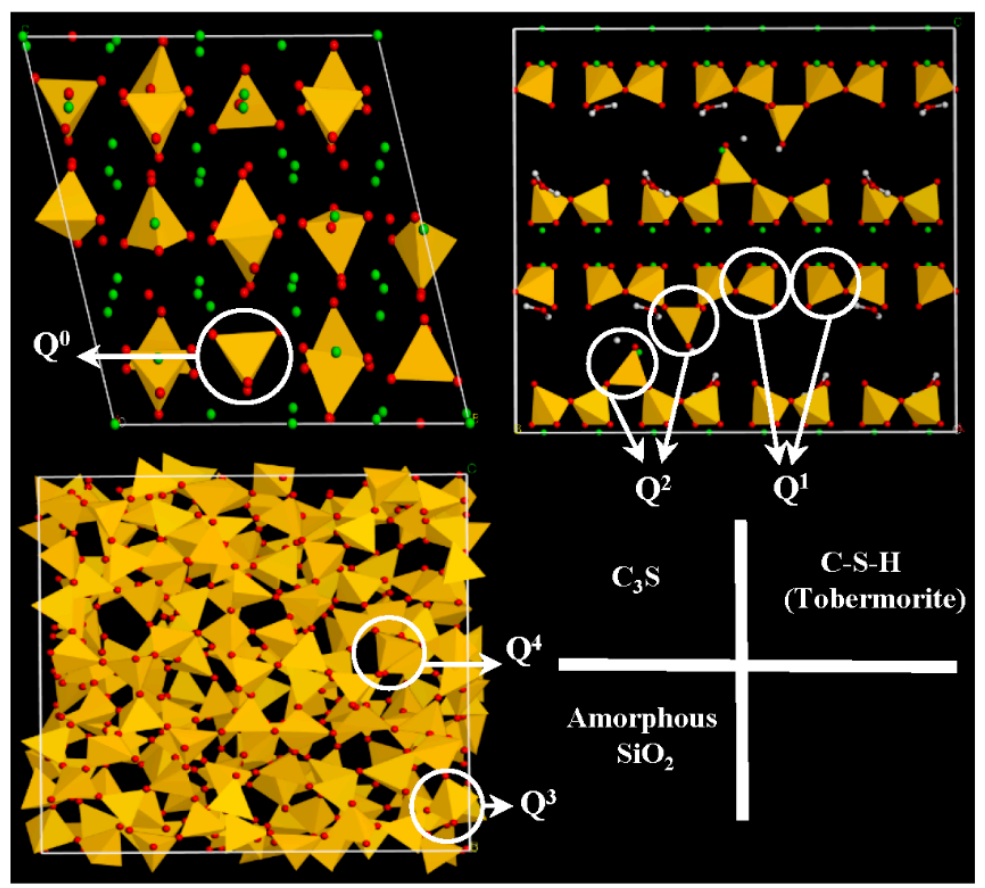

Figure 16. Molecular structure of $\mathrm{C}_{3} \mathrm{~S}, \mathrm{C}-\mathrm{S}-\mathrm{H}$, amorphous $\mathrm{SiO}_{2}$, and different $\mathrm{Q}^{\mathrm{n}}$ in their structure.
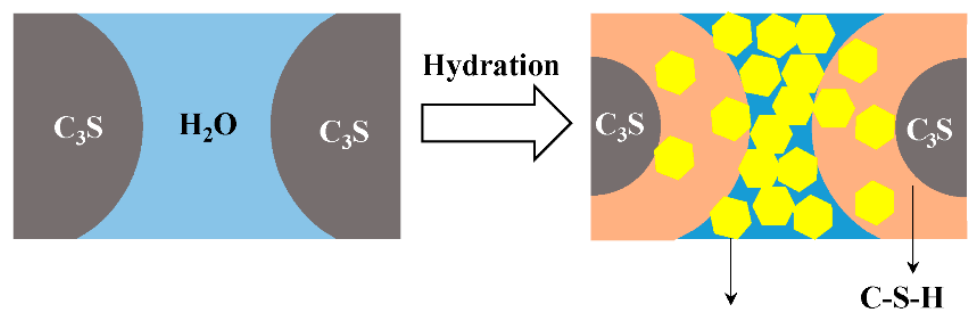

Calcium hydroxide
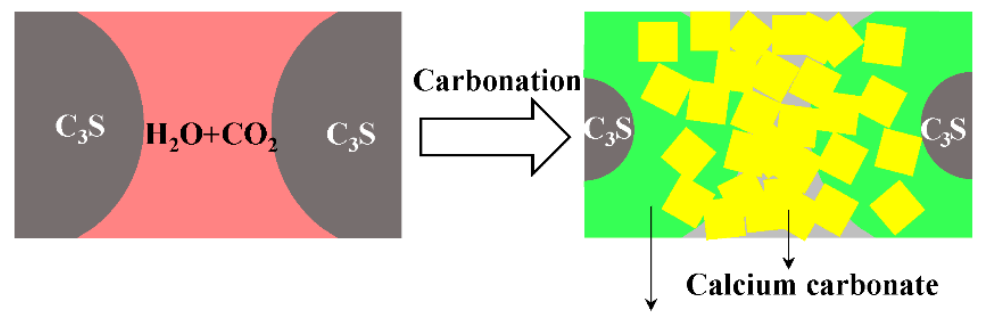

Amorphous $\mathrm{SiO}_{2}$

Figure 17. Schematic of the microstructure formation mechanism of $\mathrm{C}_{3} \mathrm{~S}$ paste hydration and carbonation.

\section{Conclusions}

In this study, the heat release characteristics and products of $\mathrm{C}_{3} \mathrm{~S}$ paste subjected to carbonation curing were studied by micro-calorimetry, TG-DTG, XRD, TEM-EDS, and ${ }^{29} \mathrm{Si}$ MAS NMR. The main conclusions drawn are as follows:

1. With the use of a micro-calorimeter under pressure of 0.5 bar, the maximum heat flow of $\mathrm{C}_{3} \mathrm{~S}$ paste activated by carbonation was measured at $0.54 \mathrm{~W} / \mathrm{g}$. This is 200 times higher than that of the hydration reaction with the same $\mathrm{w} / \mathrm{b}$ of 0.15 . The carbonation heat of $C_{3} S$ is $116.7 \mathrm{~kJ} / \mathrm{mol}$, which is more than three times than that of hydration. It is indicative that the carbonation 
reaction is more rapid than the hydration for $C_{3} S$ paste with $0.15 \mathrm{w} / \mathrm{b}$, and it also has a higher reaction degree than that in the hydration case. The experimental carbonation heat of $\mathrm{C}_{3} \mathrm{~S}$ is lower than that of the calculated value. This is mainly because $\mathrm{C}_{3} \mathrm{~S}$ does not completely react under experimental conditions.

2. Under 4-bar reaction pressure, the compressive strength of $\mathrm{C}_{3} \mathrm{~S}$ paste reached $27.5 \mathrm{MPa}$ by $2 \mathrm{~h}$ of carbonation, and $62.9 \mathrm{MPa}$ by $24 \mathrm{~h}$ of carbonation. The compressive strength of the sample with $24 \mathrm{~h}$ of carbonation exceeded that of the 24-h hydration reference, and even exceeded that of the sample with 28 days of hydration.

3. Based on the TG-DTG data, the $\mathrm{CO}_{2}$ uptake by $\mathrm{C}_{3} \mathrm{~S}$ paste carbonated for $2 \mathrm{~h}$ and $24 \mathrm{~h}$ reached $17.17 \%$ and $26.32 \%$, respectively. This is evident that the materials containing $C_{3} S$ can have a high potential to absorb carbon dioxide through curing for the application of low-carbon products. It applies to Portland cement-based products.

4. The maximum $\mathrm{CO}_{2}$ uptake of $\mathrm{C}_{3} \mathrm{~S}$ paste is tested under experimental conditions. Through the addition of water and repeated carbonation, the $\mathrm{CO}_{2}$ uptake of $\mathrm{C}_{3} \mathrm{~S}$ paste can go up to $51.11 \%$.

5. The carbonation products of $\mathrm{C}_{3} \mathrm{~S}$ paste are mainly calcite crystal and amorphous $\mathrm{SiO}_{2}$, which is confirmed by TG-DTG, XRD, TEM-EDS, and ${ }^{29} \mathrm{Si}$ MAS NMR. They are independent from carbonation degree and duration.

Author Contributions: Z.H. and Z.L. conceived and designed the experiments; Z.L. performed the experiments; Z.L., Z.H. and Y.S. analyzed the data; Z.L. wrote the paper; Y.S. polished the language.

Funding: This research was funded by [China Ministry of Science and Technology] grant number [2015CB655101] and [National Natural Science Foundation of China] grant number [51379163].

Acknowledgments: We thank Lingling $\mathrm{Hu}$ and Xiaorun Chen for selfless help.

Conflicts of Interest: The authors declare no conflict of interest.

\section{References}

1. Rostami, V.; Shao, Y.; Boyd, A.J. Durability of concrete pipes subjected to combined steam and carbonation curing. Constr. Build. Mater. 2011, 25, 3345-3355. [CrossRef]

2. Zhang, D.; Shao, Y. Effect of early carbonation curing on chloride penetration and weathering carbonation in concrete. Constr. Build. Mater. 2016, 123, 516-526. [CrossRef]

3. El-Hassan, H.; Shao, Y. Carbon storage through concrete block carbonation. J. Clean Energy Technol. 2014, 2, 287-291. [CrossRef]

4. El-Hassan, H.; Shao, Y. Early carbonation curing of concrete masonry units with portland limestone cement. Cem. Concr. Compos. 2015, 62, 168-177. [CrossRef]

5. Zhang, D.; Cai, X.; Shao, Y. Carbonation curing of precast fly ash concrete. J. Mater. Civ. Eng. 2016, 28, 04016127. [CrossRef]

6. Zhang, D.; Shao, Y. Early age carbonation curing for precast reinforced concretes. Constr. Build. Mater. 2016, 113, 134-143. [CrossRef]

7. He, Z.; Li, Z.; Shao, Y. Effect of carbonation mixing on $\mathrm{CO}_{2}$ uptake and strength gain in concrete. J. Mater. Civ. Eng. 2017, 29, 04017176. [CrossRef]

8. Goodbrake, C.J.; Young, J.F.; Berger, R.L. Reaction of beta-dicalcium silicate and tricalcium silicate with carbon dioxide and water vapor. J. Am. Ceram. Soc. 1979, 62, 168-171. [CrossRef]

9. Berger, R.L.; Young, J.F.; Leung, K. Acceleration of hydration of calcium silicates by carbon dioxide treatment. Nat. Phys. Sci. 1972, 240, 16-18. [CrossRef]

10. Berger, R.L.; Klemm, W. Accelerated curing of cementitious systems by carbon dioxide: Part ii. Hydraulic calcium silicates and aluminates. Cem. Concr. Res. 1972, 2, 647-652. [CrossRef]

11. Young, J.F.; Berger, R.L.; Breese, J. Accelerated curing of compacted calcium silicate mortars on exposure to $\mathrm{CO}_{2}$. J. Am. Ceram. Soc. 1974, 57, 394-397. [CrossRef]

12. Goto, S.; Suenaga, K.; Kado, T.; Fukuhara, M. Calcium silicate carbonation products. J. Am. Ceram. Soc. 1995, 78, 2867-2872. [CrossRef] 
13. Shtepenko, O.; Hills, C.; Brough, A.; Thomas, M. The effect of carbon dioxide on $\beta$-dicalcium silicate and portland cement. Chem. Eng. J. 2006, 118, 107-118. [CrossRef]

14. Ashraf, W.; Olek, J. Carbonation behavior of hydraulic and non-hydraulic calcium silicates: Potential of utilizing low-lime calcium silicates in cement-based materials. J. Mater. Sci. 2016, 51, 6173-6191. [CrossRef]

15. Falke, M.; Platen, A.V. Nanoscience in sem and tem: Energy dispersive x-ray analysis with high spatial resolution. Imaging Microsc. 2010, 11, 36-39. [CrossRef]

16. Wesselsky, A.; Jensen, O.M. Synthesis of pure portland cement phases. Cem. Concr. Res. 2009, 39, 973-980. [CrossRef]

17. Dunstetter, F.; de Noirfontaine, M.N.; Courtial, M. Polymorphism of tricalcium silicate, the major compound of portland cement clinker. Cem. Concr. Res. 2006, 36, 39-53. [CrossRef]

18. Mumme, W.G. Crystal-structure of tricalcium silicate from a Portland-cement clinker and its application to quantitative XRD analysis. Neues Jahrb. Fur Miner. -Monatshefte 1995, 145-160.

19. Klemm, W.; Berger, R. Accelerated curing of cementitious systems by carbon dioxide: Part i. Portland cement. Cem. Concr. Res. 1972, 2, 567-576. [CrossRef]

20. Fang, Y.; Chang, J. Rapid hardening $\beta-\mathrm{C}_{2} \mathrm{~S}$ mineral and microstructure changes activated by accelerated carbonation curing. J. Therm. Anal. Calorim. 2017, 129, 681-689. [CrossRef]

21. Bahafid, S.; Ghabezloo, S.; Duc, M.; Faure, P.; Sulem, J. Effect of the hydration temperature on the microstructure of Class G cement: C-S-H composition and density. Cem. Concr. Res. 2017, 95, 270-281. [CrossRef]

22. Alarcon-Ruiz, L.; Platret, G.; Massieu, E.; Ehrlacher, A. The use of thermal analysis in assessing the effect of temperature on a cement paste. Cem. Concr. Res. 2005, 35, 609-613. [CrossRef]

23. Sha, W.; Pereira, G.B. Differential scanning calorimetry study of ordinary portland cement paste containing metakaolin and theoretical approach of metakaolin activity. Cem. Concr. Compos. 2001, 23, 455-461. [CrossRef]

24. Han, S.; Yan, P.; Liu, R. Study on the hydration product of cement in early age using TEM. Sci. China Technol. Sci. 2012, 55, 2284-2290. [CrossRef]

25. Richardson, I.G.; Skibsted, J.; Black, L.; Kirkpatrick, R.J. Characterisation of cement hydrate phases by TEM, NMR and Raman spectroscopy. Adv. Cem. Res. 2010, 22, 233-248. [CrossRef]

26. Brinker, C.J.; Kirkpatrick, R.J.; Tallant, D.R.; Bunker, B.C.; Montez, B. NMR confirmation of strained "defects" in amorphous silica. J. Non-Cryst. Solids 1988, 99, 418-428. [CrossRef]

27. Groves, G.W.; Brough, A.; Richardson, I.G.; Dobson, C.M. Progressive changes in the structure of hardened $\mathrm{C}_{3} \mathrm{~S}$ cement pastes due to carbonation. J. Am. Ceram. Soc. 1991, 74, 2891-2896. [CrossRef]

28. Johansson, K.; Larsson, C.; Antzutkin, O.N.; Forsling, W.; Kota, H.R.; Ronin, V. Kinetics of the hydration reactions in the cement paste with mechanochemically modified cement ${ }^{29} \mathrm{Si}$ magic-angle-spinning NMR study. Cem. Concr. Res. 1999, 29, 1575-1581. [CrossRef]

29. Lippmaa, E.; Maegi, M.; Samoson, A.; Engelhardt, G.; Grimmer, A.R. Structural studies of silicates by solid-state high-resolution silicon-29 NMR. J. Am. Chem. Soc. 1980, 102, 4889-4893. [CrossRef]

30. Gopi, S.; Subramanian, V.K.; Palanisamy, K. Aragonite-calcite-vaterite: A temperature influenced sequential polymorphic transformation of $\mathrm{CaCO}_{3}$ in the presence of DTPA. Mater. Res. Bull. 2013, 48, 1906-1912. [CrossRef]

31. Gmira, A.; Zabat, M.; Pellenq, R.J.M.; Van Damme, H. Microscopic physical basis of the poromechanical behavior of cement-based materials. Mater. Struct. 2004, 37, 3-14. [CrossRef]

32. Powers, T.C. Structure and physical properties of hardened portland cement paste. J. Am. Ceram. Soc. 1958, 41, 1-6. [CrossRef]

33. Powers, T.C.; Brownyard, T.L. Studies of the physical properties of hardened portland cement paste. ACI J. Proc. 1946, 43, 101-132.

34. Richardson, I.G.; Groves, G.W. Microstructure and microanalysis of hardened ordinary portland cement pastes. J. Mater. Sci. 1993, 28, 265-277. [CrossRef]

35. Kumar, A.; Bishnoi, S.; Scrivener, K.L. Modelling early age hydration kinetics of alite. Cem. Concr. Res. 2012, 42, 903-918. [CrossRef] 
36. Lu, L.; Xiang, C.; He, Y.; Wang, F.; Hu, S. Early hydration of $\mathrm{C}_{3} \mathrm{~S}$ in the presence of $\mathrm{Cd}^{2+}, \mathrm{Pb}^{2+}$ and $\mathrm{Cr}^{3+}$ and the immobilization of heavy metals in pastes. Constr. Build. Mater. 2017, 152, 923-932. [CrossRef]

37. Bishnoi, S.; Scrivener, K.L. Studying nucleation and growth kinetics of alite hydration using $\mu$ ic. Cem. Concr. Res. 2009, 39, 849-860. [CrossRef] 